\title{
Kefektifan Model Student Teams Achivement Divison (STAD) Terhadap Keterampilan Berbicara
}

\author{
Bagas Panur Permana ${ }^{1}$, Ahmad Nashir Tsalatsa ${ }^{2}$, Mei Fita Asri Untari ${ }^{3}$ \\ 1,2,3 PGSD FIP Universitas PGRI Semarang \\ Email:Purnamabagas95@gmail.com
}

\begin{abstract}
ABSTRAK
Keefektifan Model Student Teams Achivement Division (STAD) Terhadap keterampilan Berbicara Pada Kelas V SDN Kaliwiru Semarang. Penelitian ini bertujuan untuk mengetahui keefektifan Model Teams Achivement Division (STAD). Jenis penelitian ini adalah penelitian kuantitatif dengan bentuk desain yang digunakan dalam penelitian ini adalah One-Grup Pretest-posttest design. Berdasarkan hasil analisis yang telah dilakukan rata-rata skor pretest pada mencapai 53 dan posttest mencapai 81 Berdasarkan dari uji t pada diperoleh harga thitung > ttabel yaitu $14.209>1,684$. Dengan demikian Ho ditolak dan Ha diterima. Dapat disimpulkan bahwa Model Student Teams Achievement Division (STAD) efektif terhadap keterampilan berbicara siswa kelas $V$ SD Negeri kaliwiru Semarang Tahun ajaran 2019.
\end{abstract}

Kata kunci: Keefektifan, Model pembelajaran Student Team Achievement (STAD), keterampilan berbicara.

\begin{abstract}
Effectiveness of Student Teams Achivement Division (STAD) Model on Speech Skills in Class $V$ of Kaliwiru Elementary School Semarang. This study aims to determine the effectiveness of the Model Teams Achivement Division (STAD). This type of research is quantitative research with the design form used in this study is the One-Group Pretest-posttest design. Based on the results of the analysis that has been done, the average pretest score reaches 53 and the posttest reaches 81 . Based on the t test, the tcount> ttable is 14.209>1.684. Thus $\mathrm{Ho}$ is rejected and $\mathrm{Ha}$ is accepted. It can be concluded that the Student Teams Achievement Division (STAD) model is effective against the speaking skills of fifth grade students of Semarang Kaliwiru Elementary School 2019 Academic Year.
\end{abstract}

Keywords : Effectiveness, Student Team Achievement (STAD) learning model, speaking skills. 


\section{Pendahuluan}

Pendidikan merupakan usaha sadar yang dilakukan manusia melalui berbagai proses untuk mengembangkan kemampuan sosial maupun individual, sikap, dan membentuk tingkah laku di masyarakat. Melalui pendidikan tersebut manusia akan menggali dan mengembangkan potensi-potensi yang ada di dalam dirinya serta terjadi perubahanperubahan yang bersifat tetap baik dari pemikiran, sikap, dan tingkah lakunya. Oleh karena itu, pemerintah mendukung terselenggaranya pendidikan yang tertuang dalam suatu undang- undang RI Nomor 20 tahun 2003 tentang Sistem Pendidikan Nasional).

Pendidikan sangatlah penting bagi peserta didik dengan pendidikan peserta didik mampu menguasai pengetahuan dan keterampilan yang kelak akan berguna di masyarakat. Peserta didik di harapkan mampu menerapkan pengetahuan dan keterampilanya kelak untuk membangun. Sedangkan Keterampilan Bahasa Indonesia memiliki keterampilan berbahasa, yang terdidiri atas empat aspek yaitu keterampilan menyimak atau mendengarkan (listening skils), keterampilan berbicara (speaking skils), keterampilan membaca (reading skils), dan keterampilan menulis (reading skils). Setiap keterampilan sangat berkaitan sangat berkaitan antara satu dengan yang lain. Usaha memperoleh keterampilan bahasa yang baik dan benar, seseorang mengenal dari mendengarkan. Selanjutnya berbicara dan berlatih membaca setelah melalui berbagai usaha tersebut, ia akan berusaha menulis.

Guntur Tarigan (1981:16) mengemukakan keterampilan berbicara adalah kemampuan mengucap bunyi-bunyi atrtikulasi atau kata-kata untuk mengekspresi, mengatakan serta menyampaikan pikiran, gagasan, dan perasaan. Salah satu aspek berbahasa yang harus di kuasai siswa adalah berbicara, sebab keterampilan berbicara menujang keterampilan lainnya (Tarigan,1986:6) seharusnya keteramplan berbicara di tanamkan sedini mungkin dan keterampilan berbicara penting di kuasai siswa agar mampu mengembangkan kemampuan berfikir, membaca, menulis, menyimak, dan penyampaian ide kepada orang lain secara lisan.

Menurut pengamatan dari di kelas V SDN Kaliwiru Semarang, terdapat permasalahan dalam proses pembelajaran dikarenakan guru masih menggunkan cara pembelajaran yang klasikal, Berdasarkan informasi yang didapat dari guru kelas V SDN. Salah satu aspek berbahasa yang harus dikuasai oleh siswa adalah berbicara, sebab keterampilan berbicara menunjang keterampilan lainnya (Tarigan, $1986: 6$ ).

Pentingnya penguasaan keterampilan berbicara untuk siswa Sekolah Dasar juga dinyatakan oleh Farris (Supriyadi, 2005:179) bahwa pembelajaran keterampilan berbicara penting dikuasai siswa agar mampu mengembangkan kemampuan berpikir, membaca, menulis, dan menyimak. Kemampuan berpikir mereka akan terlatih ketika mereka mengorganisasikan,mengonsepkan, mengklarifikasikan,dan menyederhanakan pikiran, perasaan, dan ide kepada orang lain secara lisan. Akan tetapi, masalah yang terjadi di lapangan adalah tidak semua siswa mempunyai kemampuan berbicara yang baik. Oleh sebab itu, pembinaan keterampilan berbicara harus dilakukan sedini mungkin. Model-model pembelajaran di rancang untuk tujuan-tujuan tertentu pengajaran konsep-konsep informasi, cara-cara berfikir, studi nilai-nilai sosial dan sebagaian dengan meminta siswa untuk terlibat aktif dalam tugas-tugas kognitif dan sosial tertentu.

Kenyataannya, tidak semua siswa mempunyai kemampuan berbicara yang baik dan tidak semua siswa dapat berpartisipasi dan aktif berbicara Masih terdapat beberapa permasalahan yang ditemukan di lapangan diantaranya: 1. Siswa kurang aktif dalam pembelajaran di kelas; 2. Masih banyak siswa kelas $\mathrm{V}$ yang mengalami kesulitan menyampaikan pendapat atau tidak dapat menjawab pertanyaan yang diajukan guru.l

Menurut pengamatan dari di kelas V SDN Kaliwiru Semarang, terdapat permasalahan dalam proses pembelajaran dikarenakan guru masih menggunkan cara pembelajaran yang klasikal, Berdasarkan informasi yang didapat dari guru kelas V SDN Menurut pengamatan dari di kelas V SDN Kaliwiru Semarang, guru sudah pernah menggunakan model pembelajaran kooperetif tipe model Picture and Picture, Pentingnya penguasaan keterampilan berbicara untuk siswa Sekolah Dasar juga dinyatakan oleh Farris (Supriyadi, 2005:179) bahwa pembelajaran keterampilan berbicara penting dikuasai siswa agar mampu 
mengembangkan kemampuan berpikir, membaca, menulis, dan menyimak. Kemampuan berpikir mereka akan terlatih ketika mereka mengorganisasikan,mengonsepkan, mengklarifikasikan,dan menyederhanakan pikiran, perasaan, dan ide kepada orang lain secara lisan. Akan tetapi, masalah yang terjadi di lapangan adalah tidak semua siswa mempunyai kemampuan berbicara yang baik. Oleh sebab itu, pembinaan keterampilan berbicara harus dilakukan sedini mungkin

Model-model pembelajaran di rancang untuk tujuan-tujuan tertentu pengajaran konsep-konsep informasi, cara-cara berfikir, studi nilai-nilai sosial dan sebagaian dengan meminta siswa untuk terlibat aktif dalam tugas-tugas kognitif dan sosial tertentu. Kenyataannya, tidak semua siswa mempunyai kemampuan berbicara yang baik dan tidak semua siswa dapat berpartisipasi dan aktif berbicara Masih terdapat beberapa permasalahan yang ditemukan di lapangan diantaranya: 1. Siswa kurang aktif dalam pembelajaran di kelas; 2. Masih banyak siswa kelas $V$ yang mengalami kesulitan menyampaikan pendapat atau tidak dapat menjawab pertanyaan yang diajukan guru.l

Menurut pengamatan dari di kelas V SDN Kaliwiru Semarang, terdapat permasalahan dalam proses pembelajaran dikarenakan guru masih menggunkan cara pembelajaran yang klasikal, Berdasarkan informasi yang didapat dari guru kelas V SDN Menurut pengamatan dari di kelas V SDN Kaliwiru Semarang, guru sudah pernah menggunakan model pembelajaran kooperetif tipe model Picture and Picture, Model Snowball Throwing dan Mind Mapping. Namun dalam Proses pembelajaran guru sangat jarang menggunakan model pembelajran pada saat pelaksanaan pembelajaran berlangsung sehingga siswa cenderung bosan saat pelaksanaan pembelajaran berlangsung sehingga pelaksanaan kegiatan belajar mengajar kurang efektif dan menyebabkan penyampaian materi oleh guru tidak di terima secara menyeluruh oleh siswa.

Berdasarkan diskripsi permasalahan di atas menunjukkan bahwa ada masalah pada kemampuan berbicara perlu di perbaiki agar dapat meningkatkan kemampuan berbicara siswa pada semua mata pelajaran dan lebih spesifik pada Kelas V Semester II. Berdasarkan latar belakang penelitian ini, dan bedasarkan masalah-masalah yang di paparkan di atas merupakan faktor utama yang melatarbelakangi peneliti untuk mengadakan penelitian yang berjudul "Keefektifan Model Student Teams Achivement Divion (STAD) Terhadap Kemampuan Berbicara Kelas V SDN Kaliwiru Semarang".

\section{Metode}

Penelitian ini merupakan penelitian ekperimen jenis kuantitatif. Penelitian ini menggunakan One Group Pretest-Posttest Design. Penelitian dilaksanakan di SD Negeri Kaliwiru Kabupaten Semarang pada tanggal 29 januari - 6 febuari 2019 pada tahun ajaran 2019 semester genap pada siswa kelas V SD Negeri Kaliwiru Kabupaten Semarang Tahun pelajaran 2019. Populasi dalam penelitian ini adalah semua peserta didik kelas IV SD Negeri Kaliwiru Kabupaten Semarang berjumlah 32 siswa tahun ajaran 2019. Desain yang digunakan dalam penelitian ini adalah One-Grup Pretest-posttest design. Desain ini terdapat pretest, sebelum di beri perlakuan. Dengan demikian hasil perlakuan dapat di ketahui lebih akurat, karena membandingkan dengan keadaan sebelum di beri perlakuan (Sugiono, 2009 : 110). Dengan gambar sebagai berikut:

$$
\begin{array}{lll}
\mathbf{O}_{1} & \mathbf{X} & \mathbf{O}_{2}
\end{array}
$$

(Sugiono, 2009 : 110).

\section{Gambar 1. One Group Pretest - Posttest Design}

O1 = Nilai pretest (Sebelum di beri perlakuan model STAD)

O2 = Nilai Posttest (Setelah di beri Perlakuan Model STAD)

O2-O1 = Pengaruh model STAD terdap keterampilan berbicara siswa 
Teknik pengumpulan data dalam penelitian ini adalah wawancara, dokumentasi dan tes. Wawancara bertujuan untuk mendapatkan informasi tentang kondisi awal siswa serta materi yang akan diajarkan. okumentasi dalam penelitian ini digunakan untuk mendapatkan dokumen sekolah mengenai nama siswa, jumlah siswa, dan data-data yang diperlukan dalam penelitian. Metode dokumentasi digunakan untuk daftar nilai, daftar nama siswa dan dokumen pelaksanaan kegiatan pembelajaran selama penelitian.

Metode tes ini digunakan peneliti ini untuk mengukur hasil belajar siswa baik yang tidak menggunakan media maupun pembelajaran yang menggunakan model STAD .Metode tes yang digunakan penelitian ini adalah : (1) Pre Test merupakan langkah awal untuk mengetahui kemampuan awal siswa mengenai pembelajaran yang disampaikan. (2) Post Test merupakan uji ekperimen yaitu test yang dilaksanakan setelah ekperimen dilaksanakan. Tujuan post test adalah untuk mendapatkan nilai sampel setelah diberi perlakuan. Peserta didik dikatakan berhasil mencapai hasil belajar jika nilainya diatas KKM, yaitu $>75$. Selain itu penilaian hasil belajar juga dapat dikategorikan menjadi 5 indikator diantaranya adalah Baik Sekali, Baik, Cukup, kurang dan sangat kurang. Pemengembangan instrument terdiri dar beberapa tahapan 1) menyusun silabus 2) menyusun rancangan pelaksanaan pembelajaran 3) membuat instrument penelitian keteramplan berbicara 4) validasi Instrumen penelitian.

Teknik analisis data merupakan cara yang digunakan untuk mengolah data hasil penelitian guna memperoleh kesimpulan. Analisis data yang digunakan dalam penelitian ini melalui beberapa tahapan, sebagai berikut: 1. Uji normalitas awal 2. Uji normalitas akir 3. Uji hipotesis (Uji T)

Untuk memudahkan perhitungan diperlukan tabel untuk mencari harga dalam melakukan uji lilliefors. Untuk menerima atau menolah hipotesis, bandingkan L0 dengan nilai kritis $L$ untuk uji lilliefors dengan $\alpha=0,05$. Jika LO < Ltabel maka H0 diterima, artinya data berdistribusi normal. Cara mengetahui adakah perbedaan hasil belajar siswa, maka digunakan Uji-t

Hasil penelitian yang telah dilaksanakan yaitu "Keefektifan Model Student Teams Achievement Division (STAD) Terhadap Keterampilan Berbicara Pada Siswa Kelas V SD Negeri Kaliwiru Semarang". Data yang diambil dari hasil penelitian ini adalah data yang diambil dari nilai siswa kelas V Penelitian ini dilaksanakan pada tanggal 29, 30 Januari dan 6 febuari 2019. Pada Kriteria Ketuntasan Minimal (KKM) kemampuan berbicara adalah 75. Dalam penelitian ini menggunakan satu kelas yang berjumlah 32 siswa Nilai tersebut menggambarkan tingkat keterampilan berbicara siswa melalui penyampaian hasil menggunakan model pembelajara STAD berdasarkan kriteria penilaian yang telah ditentukan. Gambaran secara jelas adalah sebagai berikut:

Tabel 1. Data hasil pembelajaran

\begin{tabular}{ccc}
\hline Keterangan & $\begin{array}{c}\text { Data sebelum Menggunakan } \\
\text { Model STAD }\end{array}$ & $\begin{array}{c}\text { Data sebelum menggunakan } \\
\text { Model STAD }\end{array}$ \\
\hline Nilai Tertinggi & 70 & 95 \\
Nilai Terendah & 30 & 65 \\
Rata-rata & 53 & 81 \\
\hline
\end{tabular}

Diketahui nilai siswa sebelum menggunakan Model Student Teams Achievement Division (STAD) memiliki nilai tertinggi 70 dan nilai terendah 30. Sedangkan nilai siswa setelah menggunakan Model Student Teams Achievement Division (STAD) memiliki nilai tertinggi 95 dan nilai terendah 65 sedangkan nilai rata-rata setelah menggunakan Model Student Teams Achievement Division (STAD) yaitu 81 dengan kriteria (Baik), sedangkan nilai rata-rata sebelum menggunakan Model Student Teams Achievement Division (STAD) yaitu 53 dengan kriteria (kurang). Data hasil nilai tertinggi dan nilai terendah dari posttest dan pretest diatas digambarkan dalam diagram batang dibawah ini: 


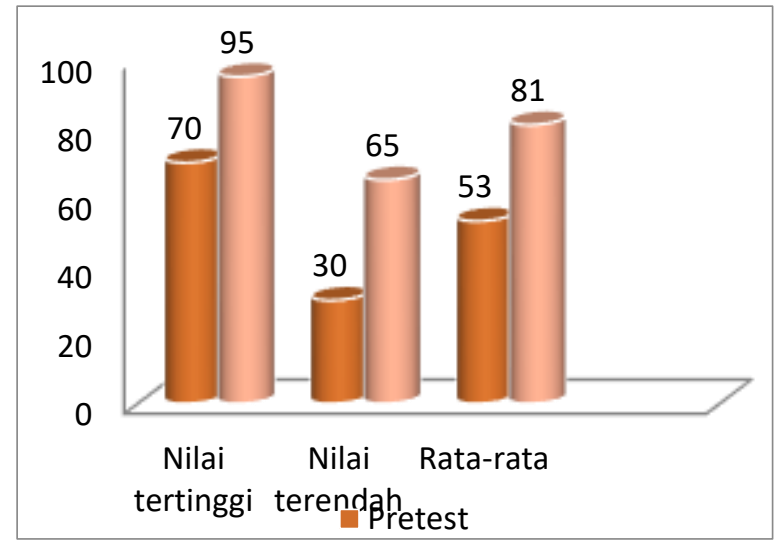

\section{Gambar 2. Diagram Nilai Tertinggi,TerendahPretest Posttest dan Rata-Rata}

Uji normalitas ini digunakan untuk mengetahui apakah sempel dari populasi berdistribusi normal atau tidak. Data yang digunakan untuk menguji normalitas awal menggunakan data nilai pretest siswa. Hal ini dilakukan untuk menentukan statistik yang digunakan dalam pengujian hipotesis. Untuk menguji kenormalan data dari sampel digunakan uji chi-kuadrat.

a) Uji Normalitas Data Awal (pretest)

Hasil perhitungan data yang diperoleh dari nilai pembelajaran sebelum menggunakan metode bermain peran terhadap keterampilan berbicara, diperoleh sebagai berikut:

Ho :Nilai pretest berasal dari ditribusi normal

Ha: Nilai pretest berasal dari populasi berdistribusi tidak normal.

Tabel 2. Hasil Uji Normalitas Data Nilai pretes

\begin{tabular}{ll}
\hline Lo & 0.127 \\
$L_{\text {table }}$ & 0.157 \\
\hline
\end{tabular}

Sumber: Hasil data 2019

Berdasarkan Tabel 4.2 dapat dijelaskan bahwa diperoleh nilai $\mathrm{LO}=0,127$ dengan taraf signifikan $5 \% \mathrm{n}=32$ maka diperoleh Ltabel $=0,157$. Karena $\mathrm{L} 0<$ Ltabel maka artinya data berdistribusi normal. Jadi data nilai pretest menunjukkan bahwa sampel berasal dari populasi berdistribusi normal.

b) Uji Normalitas Data Akhir (Posttest)

Data akhir diperoleh dari nilai posttest siswa kelas V SDN Kaliwiru Semarang. Data berasal dari soal posttest yang terdiri dari 1 petinjuk soal. Untuk mengetahui data ini perlu dilakukan uji normalitas data. Hasil perhitungan data yang diperoleh dari hasil pembelajaran sesudah menggunakan metode bermain peran terhadap keterampilan berbicara, diperoleh sebagai berikut:

Ho : Nilai posttest berasal dari ditribusi normal.

$\mathrm{Ha}$ : Nilai posttest berasal dari populasi berdistribusi tidak normal.

Tabel 3. Hasil Uji Normalitas Data Nilai Posttest

\begin{tabular}{ll}
\hline Lo & 0.115 \\
$\mathrm{~L}_{\text {tabel }}$ & 0.157 \\
\hline
\end{tabular}

Sumber: Hasil data 2019 
Berdasarkan hasil pengujian normalitas data posttest diperoleh nilai $L 0=0,115$ dengan taraf signifikan 5\% $\mathrm{n}=32$ maka diperoleh Ltabel $=0,157$. Karena LO $<$ Ltabel maka artinya data berdistribusi normal. Jadi data nilai posttest menunjukkan bahwa sampel berasal dari populasi berdistribusi normal. Data perhitungan uji normalitas pretest dan posttest diatas diperoleh dari hasil penilaian keterampilan berbicara siswa kelas V SD Negeri Kaliwiru Semarang. Pretest sebagai kemampuan awal hasil belajar siswa sebelum diberi perlakuan dan posttest sebagai kemampuan akhir hasil belajar siswa setelah diberi perlakuan dengan Model Student Teams Achievement Division (STAD). Berikut adalah hasil nilai dari hasil pretest, prosttest dan rata-rata siswa kelas V SD Negeri Kaliwiru Semarang .

Untuk mengetahui apakah model pembelajaran STAD efektif terhadap keterampilan pada kelas V SDN Kaliwiru Semarang di lakukan analisis tahap akhir berupa uji t. Hasil perhitungan menunjukkan bahwa perhitungan data siswa yang diperoleh dari hasil nilai pembelajaran sebelum dan sesudah menggunakan Model STAD keterampilan berbicara berdistribusi normal. Selanjutnya, untuk menguji perbedaan hasil belajar maka dianalisis dengan menggunakan uji t-test. Dengan hipotesis uji sebagai berikut:

HO: Jika thitung $\leq$ ttabel maka HO diterima atau dapat dikatakan bahwa Model Student Teams Achievement Division (STAD) tidak efektif terhadap keterampilan berbicara pada siswa kelas V di SDN Kaliwiru Semarang. Ha: Jika thitung $\geq$ ttabel maka Ha diterima atau dapat dikatakan bahwa Model Student Teams Achievement Division (STAD) sangat efektif terhadap keterampilan berbicara pada siswa kelas V di SDN Kaliwiru Semarang.

Rumus uji t yang digunakan adalah sebagai berikut:

$$
t=\frac{\mathrm{Md}}{\sqrt{\frac{\sum X^{2} d}{N(N-1)}}}
$$

Keterangan :

Md : Mean dari deviasi (d) antara Pretest dan Posttest

$\sum \mathrm{X}^{2}$ : Jumlah kuadrat deviasi

Xd $\quad$ : Deviasi masing-masing subjek (d-Md)

N : Banyaknya subjek pada sampel

$\mathrm{db} \quad$ : Ditentukan dengan (N-1)

Hasil analisis data akhir untuk pengujian hipotesis pada hasil belajar pretest dan posttest kelas eksperimen di dapatkan sehingga diperoleh harga thitung $>$ ttabel yaitu 14.209 $>1,684$. Dengan demikian Ho ditolak dan Ha diterima. Dapat disimpulkan bahwa Model Student Teams Achievement Division (STAD) efektif terhadap keterampilan berbicara siswa kelas V SD Negeri kaliwiru semarang Tahun ajaran 2019.

Sebelum penelitian di laksanakan peneliti mempersiapkan RPP yang di laksanakan dalam dua kali pertemuan. Penelitian ini menggunakan Model Student Teams Achievement Division (STAD) yaitu model ini penjelasan sederhananya yaitu membagi kelompok kecil yang berisikan 4-5. Siswa setiap kelompok nya siswa kelas $V$ yang memiliki jumlah siswa 32 siswa di bagi menjadi 8 kelompok. Sebelum proses posttest di laksanakan ada pretest dimana pada proses pretest ini yaitu pengambilan nilai keterampilan berbicara sebelum memberi perlakuan Model Student Teams Achievement Division (STAD) dengan membuat kesimpulan bacaan halaman 4 pada buku siswa lalu menyampaikan nya di depan kelas. Setelah pretest di laksanakanlah posttest dimana pelaksanaan posttest ini memberikan perlakuan Model Student Teams Achievement Division (STAD) pada saat pembelajaran dan di berikan posttest untuk mengetahui hasil setelah di beri perlakuan.

Dari hasil penelitian pada saat pretest terdapat nilai terendah 30 karena aspek kepercayaan diri mendapat skor 1 (perlu motivasi untuk bisa mengungkapkan), aspek kelancaran dalam mengungkapkan mendapat skor 2 (mampu mengungkapkan dengan kurang lancar), aspek keruntutan mendapat skor 1 (belum mampu mengungkapkan teks secara runtut), aspek kesesuaian dengan tema mendapat skor 1 (belum mampu 
mengungkapkan teks sesuai dengan tema), dan ekspresi mendapat skor 1 (belum mampu berekspresi dalam mengungkapkan teks).

Nilai tertinggi ketika pretest adalah 70 aspek kepercayaaan diri mendapat skor 3 (mampu mengungkapkan dengan cukup percaya diri dan mudah di mengerti, meski kadang suara kurang terdengar jelas), aspek kelancaran dalam mengungkapkan mendapat skor 3 (mampu mengungkapkan dengan cukup lancar), aspek keruntutan mendapat skor 3 (mampu mengungkapkan teks cukup runtut), aspek kesesuaian dengan tema mendapat skor 3 (mampu mengungkapkan teks cukup sesuai dengan tema) dan aspek ekspresi mendapat skor 2 (mampu mengungkapkan teks namun kurang ekspresi).

Sedangkan hasil penelitian pada saat posttest nilai terendah adalah 70 nilai ini di peroleh dari aspek kepercayaaan diri mendapat skor 3 (mampu mengungkapkan dengan cukup percaya diri dan mudah di mengerti, meski kadang suara kurang terdengar jelas), aspek kelancaran dalam mengungkapkan mendapat skor 3 (mampu mengungkapkan dengan cukup lancar), aspek keruntutan mendapat skor 3 (mampu mengungkapkan teks cukup runtut), aspek kesesuaian dengan tema mendapat skor 3 (mampu mengungkapkan teks cukup sesuai dengan tema) dan aspek ekspresi mendapat skor 2 (mampu mengungkapkan teks namun kurang ekspresi).

Nilai tertinggi pada saat posttest adalah 95 nilai ini di peroleh dari aspek kepercayaan diri mendapat skor 4 (mampu mengungkapkan dengan percaya diri, suara jelas, dan mudah di mengerti), aspek kelancaran dalam mengungkapkan mendapat skor 4 ( mampu mengungkapkan dengan lancer), aspek keruntutan mendapat skor 4 ( mampu mengungkapkan teks dengan runtut), aspek kesesuaian dengan tema mendapat skor 4 (mampu mengungkapkan teks sesuai dengan tema), aspek ekspresi mendapatkan skor 3 (mampu mengungkapkan teks dengan cukup ekspresi).

Diketahui dari siswa sebelum menggunakan Model Student Team Achivement (STAD) memiliki nilai tertinggi 70 dan nilai terendah 30. Sedangkan nilai siswa setelah menggunakan Model Student Team Achivement (STAD) memiliki nilai tertinggi 95 dan nilai terendah 65 sedankan nilai rata-rata setelah menggunakan Model Student Team Achivement (STAD) yaitu 81 dengan kriteria (Baik), sedangkan nilai rata-rata sebelum menggunakan Model Student Team Achivement (STAD) yaitu 53 dengan kriteria (kurang).

Keberhasilan model pembelajaran STAD dapat di lihat melalui sintak pembelajaran yang telah di capai yaitu:

a) Tahap Pengajaran

Pada tahap pengajaran, guru menyajikan materi pembelajaran, biasanya dengan format ceramah-diskusi. Pada tahap ini, siswa seharusnya di ajarkan tentang apa yang akan merekan pelajari dan mengapa pembelajaran itu penting. Pada tahap ini siswa mendengarkan penyampaian materi dari guru dengan baik dan kelas tenang.

b) Tim studi

Pada tahap ini, para anggota kelompok bekerja secara kooperatif untuk menyelesaikan lembar kerja dan lembar jawaban yang telah di sediakan oleh guru. Dalam proses tim studi atau pembemtukan kelompok siswa melaksanakan dengan baik dalam berdiskusi mengamati gambar pada buku siswa secara teliti dan saling bertukar pendapat tentang soal yang ada di buku siswa, hal ini membuat siswa lebih terampil dalam bberbicara karena siswa secara tidak langsung mengasah kemampuan berbicara dan keterampilan berbicara mereka dan siswa merasa lebih nyaman berlajar dalam kelompok dari pada belajar secara individu

c) Tes

Pada tahap ujian, setiap siswa secara individu menyelesaikan kuis. Guru men-score kuis tersebut dan mencatat pemerolehan hasilnya saat itu serta hasil kuis pada pertemuan sebelumnya. Hasil dari tes individual akan di akumulasikan untuk skor tim mereka. Pada tahap tes ini siswa di tuntut untuk membuat laporan tentang pengamatan soal yang ada pada buku siswa yang berisi empat kalimat kemudian masing masing siswa memaparkan hasil pengamatan di depan kelas secara individu dan urut presensi, pada tahap ini siswa mampu memaparkan hasil laporan dengan baik dan lebih percaya diri dari pada saat pelaksanaan pretest dan kondisi kelas cenderung tenang saat para siswa memaparkan hasil 
pengamatan mereka. Dari sikap yang di tunjukkan oleh siswa menunjukkan sikap menghargai orang lain saat berbicara di depan dan sikap ini belom di miliki para siswa saat observasi dan pelaksanaan pretest.

d) Rekognisi

Setiap tim menerima penghargaan atau reward bergantung pada skor rata-rata tim. Dari penghargaan untuk siswa saya sepakat dengan guru kelas untuk memasukkan nilai sikap sebagai tambahan nilai ulangan harian mereka di tema 6 sub tema 1, tetapi pengharhaan ini tidak di sampaikan di awal penerapan model STAD ini jadi penghargaan ini di berikan sebagai kejutan untuk para siswa.

Hasil penelitian ini memperkuat hasil penelitian yang relevan yang dilaksanakan olehPutra (2013) yang menyatakan bahwa model pembelajaran kooperatif tipe STAD berpengaruh terhadap hasil belajar matematika siswa kelas V SD Gugus Ubud Tahun Ajaran 2012/2013. Hal tersebut terjadi karena model STAD dapatmembantu dan memotivasi semangat untuk berhasil bersama.

\section{Simpulan dan Saran}

Berdasarkan hasil penelitian yang dilakukan peneliti pada siswa kelas V SD N Kaliwiru Semarang, maka dapat disimpulkan bahwa Model Student Teams Achievement Division (STAD) efektif terhadap keterampilan berbicara siswa kelas V SD N Kaliwiru Semarang. Hal ini diperkuat dengan rata-rata niali posttest adalah 81 dan nilai rata-rata pretes adalah 51 . Berdasarkan uji statistik dapat diketahui dari perhitungan uji-t dalam hipotesis, yaitu bahwa thitung lebih besar sama dengan dari ttabel dengan perhitungan $14,209 \geq 1,684$ pada taraf signifikan $5 \%$.

Dari hasil penelitian, maka saran yang dapat diajukan adalah sebagai berikut : 1. Guru dapat menggunakan dan menerapkan model STAD untuk diterapkan pada saat pembelajaran berlangsung dan mampu meningkatkan hasil belajar siswa. 2. Peneliti lain dapat menggunakan penelitian ini sebagai referensi dan menggunakan model STAD dalam upaya meningkatkan keterampilan berbicara pada anak sekolah dasar.

\section{Daftar Pustaka}

Adi, I N. S. M. \& N. N. Padmadewi, N. M. Ratminingsih.2017." The Effect Of Stad Upon Students With Different Level Of Self Esteem Toward Reading Comprehension Of Eleventh Grade Students Of Sman 1 Kediri Tabanan In The Academic Year 2013/2014". International Journal of Language and Literature Vol 1, No 3 (2017).

Adrian Yudha, S Degeng I Nyoman, Utaya Sugeng. 2016. Pengaruh Pembelajaran Kooperatif Stad Terhadap Retensi Siswa Kelas V Sekolah Dasar. Bandung: Jurnal Pendidikan: Teori, Penelitian, dan Pengembangan Volume: 1 Nomor: 2 Bulan Februari Tahun 2016

Arsjad, G Maidar. 1988. Pembinaan kemampuan Berbicara Bahasa Indonesia. Jakarta: Erlangga.

Darsono, Max, Nugroho DKK. 2001. Belajar Dan Pembelajaran. Semarang: CV IKIP SEMARANG PRES.

Huda, Miftahul. 2013. Model-Model Pengajaran Dan Pembelajaran. Malang: Pustaka Pelajar.

Indrawati, Ni Luh Gede Eka. 2017. "Penerapan Model Pembelajaran Kooperatif Tipe Student Team Achievement Divisions (Stad) Untuk Meningkatkan Hasil Belajar Matematika Siswa Kelas VI SD No. 1 Sading Kecamatan Mengwi Kabupaten Badung Semester I Tahun Pelajaran 2016/2017". Journal of Education Action Research Vol 1, No 2 (2017): August 2017. 
Jayano,Dw. Md. R. Dwi \& I Gst. Ngr. Japa I Md. Tegeh.2013." Pengaruh Model Pembelajaran Kooperatif Tipe Stad Bermuatan Catur Pramana Terhadap Hasil Belajar Matematika Kelas V Sdn 1 Sangsit”. MIMBAR PGSD Undiksha Vol 1, No 1 (2013).

Kelas IV Sekolah Dasar Nomor 3 Legian - Badung.

Kusdaryani wiwik \& Suharto Agus. 2009. Pengantar IImu Pendidikan. Semarang: Fip IKIP PGRI Semarang.

N. Puspawati, W. Lasmawan, N. Dantes. 2013. Pengaruh Model Pembelajaran Kooperatif Tipe STAD Terhadap Minat dan Prestasi Belajar IPS pada Siswa

Nara, Hartini \& Siregar Eveline. 2010. Teori Dan Pembelajaran. Jakarta: Ghalia Indonesia.

Ngalimun. 2016. Strategi Dan Model Pembelajaran. Yogyakarta: Aswaja Pressindo

Ni Made Sunilawati, Nyoman Dantes, I Made Candiasa. 2013. Pengaruh Model Pembelajaran Kooperatif Tipe Stad Terhadap Hasil Belajar Matematika Ditinjau Dari Kemampuan Numerik Siswa Kelas IV SD

Putra. 2013. "Pengaruh Penerapan Model Pembelajaran Kooperatif Tipe STAD Terhadap Hasil Belajar Matematika Siswa Kelas V SD Gugus Ubud". Univesitas Pendidikan Ganesha, Volume 1.

Rahmayunita, husnahusna. (2016). Keefektifan Model STAD dengan Media video Klip dalam Pembelajaran Menulis Cerpen Kelas X SMA. Pendidikan Bahasa dan Sastra Indonesia S1.5.8

Sabda ningtyas, Lilik, and lolianaloliana. (2018). Pengaruh Penggunaan Model Pembelajaran Kooperatif Tipe STAD Terhadap Hasil Belajar Tematik. Jurnal Pedagogi, 8(2).

Sisdiknas. 2003. Undang-Undang Republik Indonesia No.20 Tahun 2003. Semarang: Koordinator MPK-PKn IKIP PGRI Semarang.

Sudana, I Putu Ari \& I Gede Astra Wesnawa.2017." Penerapan Model Pembelajaran Kooperatif Tipe STAD Untuk Meningkatkan Hasil Belajar IPA". Jurnal IImiah Sekolah Dasar Vol 1, No 1 (2017): Februari 2017.

Sudjana, Nana \& Ahmad Rival. 2005. Media Pengajaran. Bandung: Sinar Baru Algensindo.

Sugiyono. 2016. Mtode Penelitian Kuantitatif, Kualitatif, dan R\&D, Bandung: Alfabeta.

Suprijono, Agus. 2009. Cooperativ learning. Surabaya: Pustaka Pelajar.

Tarigan, Guntur. 1979. Berbicara Sebagai Suatu Keterampilan Berbahasa.

Wahyuni. 2014. "Pengaruh Penerapan Model Pembelajaran Kooperatif Tipe STAD Berbasis Interaksi Sosial Terhadap Hasil Belajar IPS Siswa Kelas V SD”. Univesitas Pendidikan Ganesha, Volume 2. 